\title{
POST-EARTHQUAKE STRATEGIC TOURISM PLAN FOR THE MUNICIPALITY OF BOLÍVAR, MANABÍ, ECUADOR
}

\author{
Nelson GARCíA* \\ Escuela Superior Politécnica Agropecuaria de Manabí Manual Feliz López (ESPAM MFL), \\ Department of Tourism, 130250, Calceta, Manabí, Ecuador, e-mail: nelsongreinoso@gmail.com \\ Yamil DOUMET \\ Escuela Superior Politécnica Agropecuaria de Manabí Manual Feliz López (ESPAM MFL), \\ Department of Tourism, 13025o, Calceta, Manabí, Ecuador, e-mail: doumetour@hotmail.com

\section{Lorena CARREÑO} \\ Escuela Superior Politécnica Agropecuaria de Manabí Manual Feliz López (ESPAM MFL), \\ Department of Tourism, 130250, Calceta, Manabí, Ecuador, e-mail: lcarrem@yahoo.com
}

Citation: Garcia N., Doumet Y., \& Carreño L. (2018). POST-EARTHQUAKE STRATEGIC TOURISM PLAN FOR THE MUNICIPALITY OF BOLÍVAR, MANABÍ, ECUADOR. GeoJournal of Tourism and Geosites, 23(3), 881-894. https://doi.org/10.30892/gtg.23322-336

\begin{abstract}
The objective of this research is to improve tourist management after the earthquake on April 16, 2016 in the Bolívar canton, by proposing a strategic plan that responds to existing problems. The methodology employed consists of four phases: (1) post-earthquake diagnosis; (2) determine the main strengths, weaknesses, threats, opportunities and strategic positioning of the territory; (3) identify strategies based on long-term sustainable tourism planning; and the (4) proposal of the strategic plan, which as a result allowed the identification of 9 programs supported by 19 projects aimed at the improvement and reactivation of tourist attractions, basic services and commercialization.
\end{abstract}

Key words: Strategic planning, sustainable tourism, natural disasters, intervention strategies

\section{INTRODUCTION}

Tourism has become one of the most important industries in Ecuador in recent times, because it is an important source of foreign currency and contributes to the diversification of income among recipients. Tourism (Kuqi, 2018), has a great potential and plays an important role in meeting the main objectives related to, employment, sustainable economic and social development. Acording to Reyes et al., tourism is a strategic factor for economic development of the country. Tourism has an important

\footnotetext{
* Corresponding author
} 
interface role due to its complex connections to the other socio-economic sectors, to its superior use of the available resources, therefore it stimulates the local economic development, stimulating the socioeconomic system (Morar, 2012).

Domereski (2003) states that planning is a vital element in promoting tourism activities in local communities without significant damage to the environment. The nature conservation has historically been debated within the context of the biodiversity (Pletsch, et al., 2014). Learning natural values of biodiversity and geodiversity is a necessity (Bâca, 2018), because education is the basis for all planning activities, recovery and conservation of natural heritage. Morinero et al., (2013) maintain that planning is an essential process in public administration, connecting economic growth with sociocultural and environmental impacts brought by tourism.

Moreover, Moreno (2013) maintains that tourist site management must be closely related to its conservation, visitor capacity, and general commitment with all stakeholders in the development of a tourist site. For this to happen, it is necessary to assure management processes based on tools such as strategic plans that are in line with sustainability principles. At present, the small number of scientific studies addressing innovation in tourism management models represents a serious problem (Elia \& Suarez, 2015). This reality makes it necessary that institutions create strategic plans as an adequate tool for improving tourism management and for developing new tourism activities or enhancing the ones already in existence. Planning must be established on the basis of sustainability and equity, and its main objective should be to use natural and cultural resources appropriately, which in turn will improve the quality of life for local people. Tourism types and forms typologies are aiming at more effective tourism policies (Morar, 2012), also at targeting alternative local and regional development plans and marketing strategies. Planning, as stated by Doumet \& Yánez (2014) in reference to managements strategic lines, enables the creation of models for monitoring tourism activities, resulting in the development of adequate procedures especially in conservation areas. It must be taken into account that the tourism industry, as argued by Monterrubio et al. (2014), "can generate changes by itself, or in symbiosis with other change agents" such as organizations and institutions in charge of fomenting strategic plans.

Ángeles (2012) and Barra \& Gómez (2014) define strategic plans as the most common tool for optimizing resources and obtain most consistent results by setting shortterm goals with achievable tasks. For this reason, Tur-Viñes and Monserrat (2014) suggest that "tourism plans must be adaptable to every business, institution and organization for which it was created. Their flexibility must be present in every management aspect from logistics to the implementation of procedures, improving the general management and tourism reactivation. Tourism typology of the forms and types constitutes a very important tool for tourism management and planning (Morar, 2012), being essential elements in local development policies through tourism.

According to Orgaz (2013), over the years, there has been an interest in working towards developing new forms of tourism; that is the origin of sustainability and the importance of taking sustainable development activities into practice. At a time when the global economy is in a very varied period of time, the efforts for orientation for sustainable economic development have the advantage (Kuqi, 2018) of providing new solutions for decision-makers who, encourage debate on sustainable economic development. Bermejo (2014), citing the definition established by the Brundtland Report (1987), "Sustainable development is development that meets the needs of the present without compromising the ability of future generations to meet their own needs." points out that this principle can be implemented in different productive sectors, namely tourism. Madrid (2015) points out that tourism sustainability promotes and balances the 
benefits for the environment, society, and private and public tourism investments, aiming at ensuring an optimal development looking into the future.

After the devastating earthquake that took place in Chile in 2010, there is evidence of adequate planning, emphasized by PNUD Chile (2010) "Support for early postearthquake/tsunami recovery occurred in February 2010". The objective was to empower local communities to manage a sustainable recovery process after the earthquake.

The reactivation of Chile started with a baseline study on the impacts caused by the earthquake and tsunami in communities. They identified vulnerabilities, needs and risks according to threat type, which were linked to vulnerable territories and zones. The main needs and risks established in the initial study were revised for a classification of problems and needs. A general objective for an early recovery plan was formulated as follows: "reinforce the institutional and community development for physical, productive and emotional recovery". Japan was struck by an 8.9 earthquake in 2011. Gandia (2012) reports the execution of a tourism activity analysis after the disaster. He continues to state that this type of disasters is caused by tectonic activity and climate change, and it is impossible to avoid their occurrence. It is up to people to create tools for diminishing their negative effects by creating cooperation and planning culture.

In order to reactivate the tourism sector, Japan invested in strategic planning, which was well accepted by the people because of their awareness of the importance of tourism for the economy. The plan was executed by means of a baseline study that enabled the decision making on the necessary actions to reactivate tourism.

Both Chile and Japan showed high levels of tourism planning after a severe earthquake, and showed that with planning, it is possible to fully recover from this type of disasters through sustainable use of natural and cultural resources by cooperatively working with all stakeholders. According to Rodriguez-Rodriguez (2012), after experimenting the earthquake in Colombia in 1999, they proposed seven basic principles for spatial planning after a disaster. This guideline should be used in all types of planning. The principles go as follows: integral development, community participation, transparency, celerity, efficiency, sustainability, and decentralization. Therefore, it is necessary the integration and publication of planning actions involving all stakeholders.

The spatial characterization of a territory is obtained from a large number of factors, as argued by Silva et al., (2012), which consequently result in the definition of forms of occupations and territory use. Spatial planning is regarded as highly important because of the need for a correct use of territories for contributing to sustainable development. On April 16, 2016, an earthquake of magnitude 7.8 on the Richter scale shakes the northwest coast of Ecuador; the event caused great losses to the tourism sector. The National Secretary of Planning and Development of Ecuador (SENPLADES, 2016) recorded losses of USD 3344 million in total, money that would be required to rebuild the affected areas that harm more than 21,00o people directly and indirectly. In the province of Manabí the hotel, food and entertainment sector was destroyed by $80 \%$. In the tourism subsector, a total reconstruction cost of $97 \mathrm{MM}$ USD $(9.4 \%$ of the productive sector) was estimated, which includes the cost of the immediate response to the event, the reconstruction of assets and the lost flows. The subsector had significant effects on assets: $22.2 \%$ of total assets recorded in 2014 were lost in the affected area. 98.6\% of these damages are concentrated in small companies. The assets that were most affected correspond to buildings and facilities belonging mainly to small businesses, micro-enterprises and individuals. The reconstruction of assets in the tourism sub-sector amounts to USD 76.8 million. The losses for the tourism subsector are estimated at USD 19.5 million, which represent close to $13.3 \%$ of the annual sales prior to the earthquake (General Secretariat of Risks of Ecuador, 2016). 
The cost of rebuilding this infrastructure sector amounts to USD 862 million, a figure that represents $25.8 \%$ of the total amount of the reconstruction of the country. Of this amount, $89.6 \%$ corresponds to the reconstruction of assets, $7.3 \%$ to additional costs and $3.1 \%$ to lost flows. Likewise, $31.2 \%$ of cost corresponds to water and sanitation, $\mathbf{2 8 . 3 \%}$ to transportation, $22.7 \%$ to electricity and the remaining $17.7 \%$ to telecommunications (General Secretariat of Risks of Ecuador, 2016). García et al., (2016) maintain that the post-earthquake tourism industry in Manabí must be restated and adjusted to the existing reality. It is necessary to diagnose current tourism resources, evaluate damages, identify problems and causes of stagnation in the tourism industry, recognize the needs of service providers who were affected by the earthquake, redesign new products oriented to increasing local demand, and implement strategies to foster the industry through communication and destination marketing. The scholar also claims that the Municipality of Bolívar has sufficient natural and cultural resources, which have not been suitably developed. In addition, there are no adequate procedures that interlace public and private institutions for strengthening and managing the tourism industry in a more efficient manner.

It is possible to affirm that an inadequate management results in insufficient basic services. This is also reflected in the lack of tourist facilities and businesses. In the absence of clear methodological procedures, the tourism industry is affected by poor implementation of sustainable development plans, inaccessibility to tourist resources, no tourist signs and unawareness of environmental management actions by the communities. There is currently deficient planning in the canton of Bolívar. Tourism management is visibly stagnant; this reality has even worsened after the earthquake on April $16^{\text {th }}$ 2016. The municipality does not have a mechanism for responding to natural disasters. It is thus of utmost importance that the municipality have a strategic plan, which restructures and improves tourism management based on current needs.

The above-mentioned problems justify this research by validating the need for identifying and implementing strategies that are addressed towards activating tourism in Bolívar after the last earthquake. This can be possible through the creation of new products and services based on strategic planning that must be adapted to the local context. This research comes as the result of executing a Research and Development project $(\mathrm{I}+\mathrm{D}+\mathrm{i}$, in Spanish) designed to improve local tourism management and wellbeing. Through a strategic tourism plan, it will be possible for Bolívar to see a recovery after the earthquake, and promote its tourist attractions more sustainably. We propose that only through planning, development and rigorous management, the benefits of tourism can be optimized. Furthermore, through the mitigation of risks, resources will be protected, creating jobs and positioning Bolívar towards an efficient post-earthquake management.

\section{MATERIALS AND METHODS}

The methodology of this study enabled the creation of a strategic plan directed towards improving the tourism management in Bolívar after the April $16^{\text {th }}$ earthquake. Our initial point was a diagnosis of the current situation of the local tourism management after the earthquake. We evaluated the conditions of the resources and facilities, and identified problems in connection with tourism management. Planning is thus conducted in order to identify sustainable strategies through the implementation of programs and projects directed toward improving the tourism management in Bolívar. For the purpose of this paper, we followed the methodologies published from The Ecuadorian Ministry of Tourism (2007); Ecuadorian Strategic Plan for Tourism Development (PLANDETUR, 2020); Methodology for Formulating Local Development Strategies (Silva \& Sandoval, 2012); Japan: Encouraging Tourism and Improving the Image of the Destination. 
Analysis of the Before and After a Natural Disaster (Gandía, 2012); Chilean National Tourism Strategy (Chilean Government, 2012); Preliminary Design of the Tourism Development Plan for Selected Municipalities in the Province of Mayabeque, Cuba (Echarri \& Bulnes, 2015). We present a summary of our methodology in table 1.

Table 1. The proposed methodology for a strategic plan design for the Municipality of Bolívar

\begin{tabular}{|c|c|c|}
\hline PHASES & ACTIVITIES & TOOLS AND TECHNIQUES \\
\hline $\begin{array}{l}\text { Situational } \\
\text { baseline study of } \\
\text { current tourism } \\
\text { management in } \\
\text { Bolívar after the April } \\
\text { 16th earthquake. }\end{array}$ & $\begin{array}{l}\text { 1. IN-SITU information survey } \\
\text { activities on: socioeconomics, } \\
\text { environment and culture. } \\
\text { 2. Inventory and categorization of } \\
\text { natural and cultural tourism assets. } \\
\text { 3. Problems and causes affecting } \\
\text { management after the April } 16^{\text {th }} \\
\text { earthquake. }\end{array}$ & $\begin{array}{l}\text { - Maps, global positioning } \\
\text { system (GPS) and geographical } \\
\text { information system (GIS). } \\
\text { - Photographic record. } \\
\text { - Tourist destination } \\
\text { inventory forms from the } \\
\text { Ministry of Tourism. } \\
\text { - Interviews. Surveys. }\end{array}$ \\
\hline $\begin{array}{l}\text { 2. Determine the } \\
\text { strategic positioning } \\
\text { of the tourism } \\
\text { management in Bolivar. }\end{array}$ & $\begin{array}{l}\text { 4. Identify the problem and } \\
\text { solution to strategic positioning. }\end{array}$ & $\begin{array}{ll}\text { - } & \text { Technical visits. } \\
\text { - } & \text { BWainstorming. } \\
\text { SWOT analysis. }\end{array}$ \\
\hline 3. Identify strategies. & $\begin{array}{l}\text { 5. Determine the strategies } \\
\text { directed toward strengthening } \\
\text { tourism management and recovery } \\
\text { after the earthquake. }\end{array}$ & $\begin{array}{l}\text { Revision and analysis of } \\
\text { collected data. }\end{array}$ \\
\hline $\begin{array}{l}\text { 4. Establish the } \\
\text { strategic plan } \\
\text { proposal. }\end{array}$ & $\begin{array}{l}\text { 6. Establish the programs and } \\
\text { projects that enable the fulfilment } \\
\text { of strategies. } \\
\text { 7. Evaluation and monitoring of } \\
\text { the strategic plan proposal based } \\
\text { on the identified problems. }\end{array}$ & $\begin{array}{l}\text { - Spatial and Territorial } \\
\text { Development Plan of Bolívar. } \\
\text { - Technical document of } \\
\text { plan design for improving } \\
\text { tourism management. } \\
\text { - Strategic plan matrix. }\end{array}$ \\
\hline
\end{tabular}

The proposed methodology is composed of the following phases:

Phase 1: Situational baseline study of current tourism management in Bolivar after the April 16th earthquake: in-situ information compilation of various aspects such as socioeconomics, environment and culture for carrying out a situational baseline study of tourism management in Bolívar. An inventory of Bolivar's tourism resources is performed with the aim of verifying their current conditions and existence. In this phase, we used maps, GPS, GIS, photographic and written records collected by means of a technical inventory forms from the Ministry of Tourism. The final part consisted of a categorization of resources and identification of their potential for tourism after the earthquake. We identified the problems and causes affecting tourism management after the April $16^{\text {th }}$ earthquake through surveys, interviews to public employees of the Bolívar Department of Tourism, tourist managers (private and customers/visitors) to identify problems, causes and consequences, all of which will enable the improvement of the tourism management.

Phase 2: Determine the strategic positioning of the tourism management in Bolivar through a SWOT analysis, which identified the strengths, opportunities, weaknesses and threats of current tourism management. The most relevant findings enabled us to pinpoint the problem and suggest strategic solutions.

Phase 3: Identify strategies that are oriented to enhancing tourism management in Bolívar and recovery after the earthquake on the basis of a revision and analysis of previously-collected data. Thus, strategy selection sought to improve the current positioning to achieve expected results. 
Phase 4: Establish the strategic plan proposal for improving tourism management in Bolívar by considering the actions and indicators that enable the fulfilment of programs and projects based on the strategies to mitigate and eliminate the identified problems. The plan must be linked to the Spatial and Territorial Development Plan of Bolívar for evaluating and monitoring the execution of the strategic plan proposal.

\section{RESULTS DISCUSSIONS}

Phase 1: Situational baseline study of current tourism management in Bolívar after the April 16th earthquake

We present the details of the evaluation and characterization of the study area through the gathered information on geographical aspects, as shown in Table 2.

Table 2. Bolívar General Information

(Source: Spatial and Territorial Development Plan, Municipality of Bolívar, 2015)

\begin{tabular}{|l|l|}
\hline \multicolumn{1}{|c|}{$\begin{array}{c}\text { Location } \\
\text { Astronómica }\end{array}$} & $\begin{array}{c}\text { O degrees, 50 minutes and 39 seconds south, } \\
\text { and 80 degrees, 9 minutes and 33 seconds west }\end{array}$ \\
\hline Limits & $\begin{array}{l}\text { North: Chone } \\
\text { South: Portoviejo and Junín } \\
\text { East: Pichincha } \\
\text { West: Tosagua }\end{array}$ \\
\hline Main Territories & Calceta (urban), Quiroga y Membrillo (rural) \\
\hline Area & $537.8 \mathrm{Km}^{2}$ \\
\hline Population & 40.735 \\
\hline Hidrography & Carrizal River (main) \\
\hline Temperature & $25,5^{\circ} \mathrm{C}$ (mean annual temperature) \\
\hline Annual precipitation & $1.300 \mathrm{~mm}$. \\
\hline Height & $21-400$ m.a.s.l. \\
\hline
\end{tabular}

In-situ information collection of socioeconomic, environmental and cultural aspects

Bolívar has, to a large extent, an agricultural economy. Its main products are cocoa, coffee, and citrus. The topography is flat in the low lands and irregularly broken in the uplands. The mountains are known for having been a natural reservoir for forest with diverse vegetation and pleasant weather conditions. However, over the last years, some areas have been degraded due to timber exploitation and enlargement of the agricultural frontier for cattle and swine breeding.

In terms of the culture, Bolívar still has vibrant expressions of popular Manabí cultures, being a mixture of autochthonous ancestral roots and the acculturation effects of the Spanish conquest. The traditional gastronomy still prevails with exquisite dishes such as the famous tonga (chicken stew and rice wrapped in plantain leaves), free-range chicken soup and stew, cuajada (soft cheese), among others. Unfortunately, the public clock, one of the main tourist attractions, collapsed during the April $16^{\text {th }}$ earthquake.

\section{Inventory and categorization of natural and cultural assets}

We here present the tourist resources and attractions of Bolívar registered and categorized after the earthquake using inventory forms from the Ecuadorian Ministry of Tourism. The results are shown in table 3. We confirmed that the earthquake in fact affected a large number of tourist assets in Bolívar. An example of this are the San Agustin Temple, the Los Platanales bathing establishment and Abdón Calderón Park.

Other attractions collapsed (e.g. Public Clock and Luis Félix López Archaeological Museum), overall constituting a significant loss for the local tourism sector and culture. Despite the adverse consequences of the last disaster, there are still several natural 
resources such Mil Pesos Mount and the large number of waterfalls. With an adequate tourism management, they could become an important piece for the recovery of tourism in the area in a sustainable manner.

Table 3. Tourist attraction inventory of Bolívar

\begin{tabular}{|c|c|c|c|c|}
\hline No. & Attraction or resource name & Category & Current condition & Rank \\
\hline 1 & $\begin{array}{c}\text { Balneario de agua dulce Los } \\
\text { Platanales (Bathing establishment) }\end{array}$ & Natural site & $\begin{array}{l}\text { Damages } \\
\text { to facilities }\end{array}$ & II \\
\hline 2 & $\begin{array}{c}\text { Balneario de agua dulce Los } \\
\text { Almendros (Bathing establishment) }\end{array}$ & 1 site & Preserved & II \\
\hline 3 & Cascada Chapulí (Waterfall) & 1 site & In dete & II \\
\hline 4 & Cascada Julean(Waterfall) & l site & In de & II \\
\hline 5 & Cascada La Mina (Waterfall) & ll site & In de & I \\
\hline 6 & Cascada Primera Piedra (Waterfall) & Natural site & In deterioration & II \\
\hline 7 & Cerro Mil Pesos (Mount) & Natural site & In deterioration & $\mathrm{I}$ \\
\hline 8 & Clay handic & Cultural 1 & & $\mathrm{I}$ \\
\hline 9 & $\begin{array}{r}\text { Finca A } \\
(\mathrm{Ag}\end{array}$ & $\begin{array}{r}\text { Cultural r } \\
/ \mathrm{Nat} \\
\end{array}$ & $\operatorname{Pr}$ & II \\
\hline 10 & $\begin{array}{r}\text { Iglesia Sant } \\
(\mathrm{Ca}\end{array}$ & $\mathrm{n}$ & Structural damages & I \\
\hline 11 & Monumento a Sir & Cultu & & II \\
\hline 12 & Monumen & Cultura & & II \\
\hline 13 & $\begin{array}{l}\text { Museo Arqueo } \\
\text { López (Ar }\end{array}$ & tion & $\begin{array}{l}\text { Colla } \\
\text { the } \mathrm{e}\end{array}$ & - \\
\hline 14 & $\begin{array}{l}\text { al Quinta } \\
\text { al site) }\end{array}$ & $\begin{array}{r}\text { Cultura } \\
/ \mathrm{N}\end{array}$ & Preserved & II \\
\hline 15 & Parque Central A & Cultural & Structu & II \\
\hline 16 & Parque & Cultural & & II \\
\hline 17 & Parque c & Cultural $\mathrm{n}$ & & I \\
\hline 18 & & Cultural m & red & $\mathrm{I}$ \\
\hline 19 & Plaza Cívica (Public square) & Cultural manifestation & Structural damages & II \\
\hline 20 & Puente Rojo (Bridge) & Cultural manifestation & Preserved & II \\
\hline 21 & $\operatorname{Re}$ & $\mathrm{C}$ & $\begin{array}{l}\text { Collapsed during } \\
\text { the earthquake }\end{array}$ & - \\
\hline 22 & 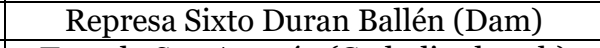 & cuitur ar & erved & II \\
\hline 23 & Templo San Agustín (Catholic church) & Cultural manifestation & Structural damages & II \\
\hline
\end{tabular}

\section{Problems and causes affecting management after the April $16^{\text {th }}$ earthquake}

We carried out interviews and surveys for identifying the problems and causes affecting the tourism management in Bolívar. Participants were the people involved in local tourism activities and some representatives from the Tourism and Planning Departments of the Bolivar District. We gathered the following information:

- The Spatial and Territorial Development Plan is currently being publicized, despite the fact that it should have been applied since 2015 .

- There is no record of a technical document comprising a strategic tourism plan for adequate management.

- One of the main causes for inefficiency in local planning is the limited budget, especially in the sectors that generate income such as agriculture and tourism.

- The tourism sector does not have long-term planning. The actions only address current needs.

We conducted surveys to the private tourism sector (21 establishments), using the 
required sample size for inferential statistics. Results are as follows:

- $88 \%$ of tourism establishments have been affected by the April $16^{\text {th }}$ earthquake.

- $82 \%$ have basic services, but not in optimal conditions. $53 \%$ of establishments lacked drinking water, followed by $29 \%$ internet service, $12 \%$ telephone service and $6 \%$ electricity.

- $41 \%$ have expressed that they have never been visited by the Bolívar Department of Tourism for evaluation purposes.

- $76 \%$ of business owners think that the Department of Tourism could significantly contribute to solving their problems, while $24 \%$ agree that the department could not give them the appropriate support.

- Currently, $82 \%$ of the establishments have problems such as lack of training (22\%), and marketing, and basic services (18\%), respectively, whilst 6\% reported financing problems.

- $71 \%$ stated that the Department of Tourism is not adequately using their resources.

All of our results are evidence of the need for implementing a strategic plan that improves the tourism management in Bolívar joining forces with public and private businesses. An adequate tourism management will benefit local communities and will enable the execution of sustainable projects that use resources (especially nature) in a suitable manner. Surveys were conducted aiming at identifying the profiles of different visitors. Because of the relevance of identifying the type of visitors and gathering the related information, it will be possible to suggest feasible tourism projects. In determining the sample size, we used the following equation for unknown population (González \& Conde, 2011):

$$
\mathrm{n}=\frac{Z_{a d_{2}}^{2} * p * q}{d^{2}}
$$

We established a 95\% confidence level, a probability of occurrence (p) 0.5 , a probability of failure (q) 0.5 and a margin of error (d) 0.09 . The calculated sample size was 120 participants. Their answers shaped the visitor's profile shown in table 4 .

Table 4. Visitors' profile

\begin{tabular}{|l|l|}
\hline Sex & Men $53 \%$, Women $47 \%$ \\
\hline Age & $26-35$ years old $32 \%$ \\
\hline Job & General employees $22 \%$ \\
\hline Education & High school degree $55 \%$ \\
\hline Number of visits & $3-5$ times $44 \%$ \\
\hline Length of stay & 2 days $37 \%, 1$ day $32 \%$ \\
\hline How they heard about Bolivar's attractions & Word of mouth 32\%, Internet 30\% \\
\hline Travelling conditions & Accompanied by other people $72 \%$ (Family 37\%), Alone 28\% \\
\hline Transportation & Car $56 \%$, Public transportation $41 \%$ \\
\hline Visitor's motivation & $\begin{array}{l}\text { Nature and landscape } 25 \%, \text { meet family and friends } \\
19 \%, \text { traditional food } 18 \%\end{array}$ \\
\hline Suggestions for a more pleasant stay & $\begin{array}{l}\text { New tourist attractions } 23 \%, \text { Improve facilities at } \\
\text { existing attractions } 20 \%, \text { Improve service } 14 \%\end{array}$ \\
\hline Nivel de satisfacción en su visita & Neither unsatisfied nor satisfied 34\%, Satisfied $27 \%$ \\
\hline
\end{tabular}

Results show that the people who visit Bolívar are aged between 26-35, and are general employees. When visiting a tourist attractions, they are usually accompanied by family members. They mainly come to see natural resources and landscapes. Most of them suggest that there should be new attractions and improvements in the quality of service in existing destinations. Visitors believe that by improving services, the level of satisfaction will increase, which is now at an intermediate level. Now it is important to show picture abaut the earthquake in the center of Calceta: Figure 2 shows the total 
destruction caused by the earthquake to two important tourist resources of the Bolivar canton: the Public Clock and the Archaeological / Historical Museum, Luis Félix López and Figure 3 illustrates house destruction and rescue and reactivation activities.

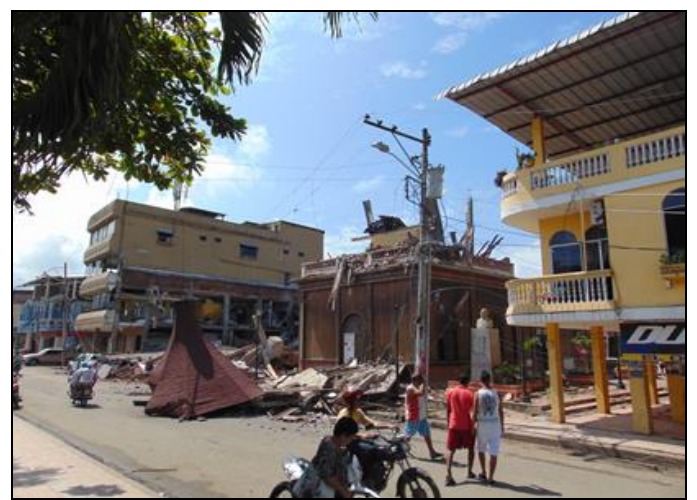

Figure 2. Public monument

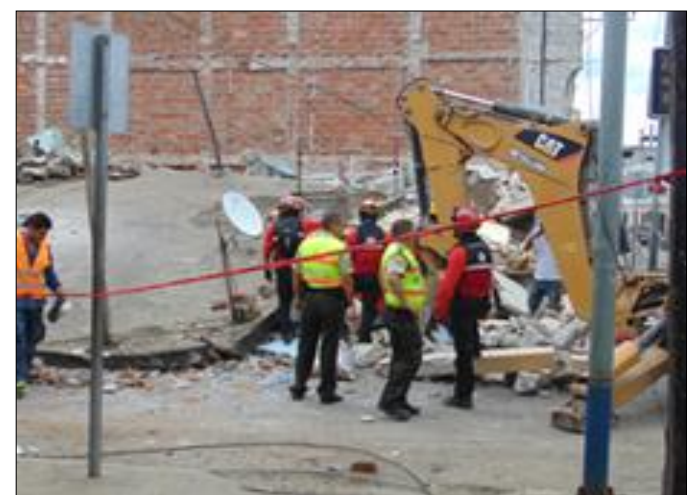

Figure 3. House destruction

Table 5. SWOT analysis

\begin{tabular}{|c|c|}
\hline & \\
\hline $\begin{array}{l}\text { Territorial Development Plan. } \\
\text { estock activities. } \\
\text { nding resources and } \\
\text { arthquake. } \\
\text { c services for the tourism sector } \\
\text { aveling in and out of Bolívar. } \\
\text { nnection with other districts. } \\
\text { ality } \\
\text { nd beautiful landscapes. } \\
\text { astronomy. } \\
\text { ber of recreational sites for } \\
\text { s willing to improve their }\end{array}$ & $\begin{array}{l}\text { less of agrotourism potential. } \\
\text { t signs. } \\
\text { ctory basic services. } \\
\text { ivers. } \\
\text { m organization and planning. } \\
\text { nt of Tourism Limited budget } \\
\text { rmation, and marketing of } \\
\text { tions. } \\
\text { gic plan for tourism } \\
\text { ated management between } \\
\text { tanies and local government. } \\
\text { pourism projects. } \\
\text { personnel in tourism companies. }\end{array}$ \\
\hline & \\
\hline $\begin{array}{l}\text { sm development. } \\
\text { tourism, } \\
\text { Iral and } \\
\text { vernment, BE, } \\
\text { ism projects }\end{array}$ & $\begin{array}{l}\text { 1. Weather conditions during the rainy season. } \\
\text { 2. Earthquakes. } \\
\text { 3. Risk of infectious and contagious diseases } \\
\text { 4. Financial instability in the local government } \\
\text { 5. Global economic crisis. } \\
\text { 6. Political instability. } \\
\text { 7. Similar attractions and services in } \\
\text { neighboring districts. } \\
\text { 8. Growing social insecurity. } \\
\text { 9. Setting up a business involves a lot of red } \\
\text { tape } \\
\text { 10. Local emigration. } \\
\text { 11. Low interest in alternative tourism supply }\end{array}$ \\
\hline
\end{tabular}




\section{Phase 2: Determine the strategic positioning of the tourism management in Bolívar}

After obtaining the results from the baseline study, we were able to determine the positioning of Bolívar in terms of its current tourism management. The SWOT analysis show the main strengths, weaknesses, opportunities and threats of the tourism management in Bolívar as shown in table 5.

\section{Identify the problem and solution to strategic positioning}

The identification of the problem and strategic solution are based on the strategic positioning that is obtained as a result of the main factors established in the SWOT analysis (Tables 6 and 7).

Table 6. Main Strengths, Opportunities, Weaknesses and Threats

\begin{tabular}{|l|l|}
\hline Strength & \#3 Large number of standing resources and attractions after the earthquake \\
\hline Opportunity & \#3 Growing trend in nature-related tourism, adventure and ecotourism \\
\hline Weakness & \#9 No strategic plan for tourism management \\
\hline Threat & \#7 Similar attractions and services in neighboring districts \\
\hline
\end{tabular}

Table 7. Strategic Positioning

\begin{tabular}{|l|l|l|}
\hline & Opportunity & Threat \\
\hline Strengths & Offensive strategy & Defensive strategy \\
\hline Weaknesses & Reorientation strategy & survival strategy \\
\hline
\end{tabular}

From the SWOT analysis, we found that the greatest weakness and threat must be countered through strategies that are based on the most important strengths and opportunities for an appropriate tourism management in Bolívar.

\section{Strategic Problem}

If similar services and products continue to be available in neighboring districts, considering the lack of a strategic plan in Bolívar and despite the fact that a large number of attractions are still standing after the earthquake, the territory will not be able to take advantage of the growing trend in ecotourism.

\section{Strategic Solution}

New proposals for minimizing the effect of the availability of similar attractions in neighboring districts should emerge, using the majority of resources and existing tourist attractions. This will overcome the lack of a strategic plan for tourism management in Bolívar.

\section{Phase 3: Identify strategies}

Determine the strategies directed toward strengthening tourism management and recovery after the earthquake

The strategic positioning establishes the need for implementing reorientation strategies because they allow the reduction of weaknesses. We present a list of strategies as follows:

- Reinforce the Department of Tourism in the local government.

- Establish institutional relationships among communities and the public and private sectors aiming at a sustainable tourism management.

- Execute projects promoting and providing information on the existing attraction in Bolívar.

- Establish a plan of action for natural disasters affecting the tourism sector.

- Improve and provide basic services in the area (with an emphasis on drinking water and sewage system).

- Cleaning programs at tourist sites and solid and liquid waste management. 
- Implement a tourist signage program in the district.

- Execute tourism projects based on sustainability principles.

- Develop new tourist attractions based on novel modalities such as gastronomy, nature, adventure and ecotourism.

- Continually train service providers and potential entrepreneurs on technical aspects related to tourism.

- Establish a program aimed at renovating resources and tourist attractions that were affected by the April $16^{\text {th }}$ earthquake.

- Add value to tourist resources and attractions that highlight the differences between Bolivar attractions and those in neighboring districts.

- Implement awareness-raising and sensitizing activities on environmental protection with the local communities.

- Manage non-refundable resources from domestic and foreign organizations for tourism projects in the area.

\section{Phase 4. Establish the strategic plan proposal}

The strategic plan is aimed at improving the tourism management in Bolívar through a partnership work between the public and private sectors, and the local community. The goal is to promote the conservation of natural and cultural tourism resources.

The mission: improve the tourism management in Bolívar through the application of a strategic plan that addresses current needs in developing tourist attractions and resources for integrating the public and private sectors involved in tourism activities.

The vision: promote Bolívar as a reference for tourism management with a successful model based on strategies in favor of sustainable development and the wellbeing of local communities.

The values: service capacity, work quality, commitment to society, discipline, efficiency, continuous improvement and responsibility.

The strategic goals in the plan are divided into three main axis:

Social Axis: implement tourism projects that generate jobs for improving the quality of life of local people.

Environmental Axis: implement environmental principles of sustainability in all tourist attractions for ensuring their conservation and availability for future generations.

Economic Axis: consolidate the tourist sector as one of the main direct and indirect sources of income for local people, utilizing the multiplying effect for positive outcome demonstrated by the industry.

\section{strategies}

Establish the programs and projects that enable the fulfilment of

We established 9 programs and 19 projects based on the problems in the current tourism management in Bolívar. The details are shown in table 8.

\section{Territorial planning: strategies for tourism development}

As a strategy to strengthen the tourism sector of the Bolívar canton, a tourist zoning is established trying to plan the territory affected by the earthquake of April 16, 2016, was designed according to the three tourism environmental units, considering the type of agricultural activities that in it develops, as well as urban-rural areas where socioproductive activities are encouraged (Figure 1). The established zones are the following:

a) Tourist core zone.

b) Agritourist use zone.

c) Sustainable use zone 
d) Wildlife and conservation zone

For more facility, we show the map whit the different zone:

Table 8. Programs and Projects

\begin{tabular}{|c|c|}
\hline Programs & Projects \\
\hline \multirow{3}{*}{$\begin{array}{l}\text { 1. Organizational and } \\
\text { institutional empowerment } \\
\text { of the Bolívar Department } \\
\text { of Tourism }\end{array}$} & 1. Improvement of internal processes. \\
\hline & 2. Reinforcement of technical capacities in human resources. \\
\hline & $\begin{array}{l}\text { 3. Elaboration and application of a data collection system for } \\
\text { tourism variables. }\end{array}$ \\
\hline \multirow{2}{*}{$\begin{array}{l}\text { 2. Interinstitutional } \\
\text { coordination for } \\
\text { sustainable development }\end{array}$} & 4. Effect of sustainable tourism on the local economy. \\
\hline & $\begin{array}{lllll}5 \cdot \quad \text { Interinstitutional } & \text { coordination } & \text { for } & \text { local } & \text { tourism } \\
\text { management. } & & & & \\
\end{array}$ \\
\hline \multirow{2}{*}{$\begin{array}{l}\text { 3. Tourism information } \\
\text { system }\end{array}$} & 6. Periodic restructure of tourism inventory. \\
\hline & 7. Elaboration of a web page. \\
\hline \multirow{2}{*}{$\begin{array}{l}\text { 4. Reinforcement of } \\
\text { integral security in tourism }\end{array}$} & 8. Action plan for disasters affecting tourism. \\
\hline & $\begin{array}{l}\text { 9. Elaboration of preventive measures for improving safety } \\
\text { during natural disasters. }\end{array}$ \\
\hline \multirow{3}{*}{$\begin{array}{l}\text { 5. Infraestructure and } \\
\text { tourism facilities }\end{array}$} & $\begin{array}{l}\text { 10. Provision and improvement plan for basic services at main } \\
\text { tourist attractions. }\end{array}$ \\
\hline & 11. Highway improvement plan for local tourism routes. \\
\hline & 12. Signage plans for urban and rural roads. \\
\hline \multirow{3}{*}{$\begin{array}{l}\text { 6. Development and } \\
\text { reinforcement of } \\
\text { sustainable tourism }\end{array}$} & $\begin{array}{l}\text { 13. Sustainable tourism project proposals in rural areas of } \\
\text { Bolívar. }\end{array}$ \\
\hline & $\begin{array}{l}\text { 14. Implementation of sustainability principles at main tourist } \\
\text { attractions existing after the April 16th earthquake. }\end{array}$ \\
\hline & 15. Promotion of cultural identity. \\
\hline $\begin{array}{l}\text { 7. Innovation in tourism } \\
\text { attractions }\end{array}$ & 16. Added value and innovation plan in local tourism activities. \\
\hline \multirow{2}{*}{$\begin{array}{l}\text { 8. Capacity development in } \\
\text { human resources for } \\
\text { sustainable tourism }\end{array}$} & 17. Technical training plans for tourism service providers. \\
\hline & $\begin{array}{l}\text { 18. Training of the importance of preserving the local } \\
\text { environment. }\end{array}$ \\
\hline $\begin{array}{l}\text { 9. Sustainable tourism } \\
\text { development fund }\end{array}$ & $\begin{array}{l}\text { 19. Management of funds for public and private initiatives and } \\
\text { sustainable tourism in communities. }\end{array}$ \\
\hline
\end{tabular}

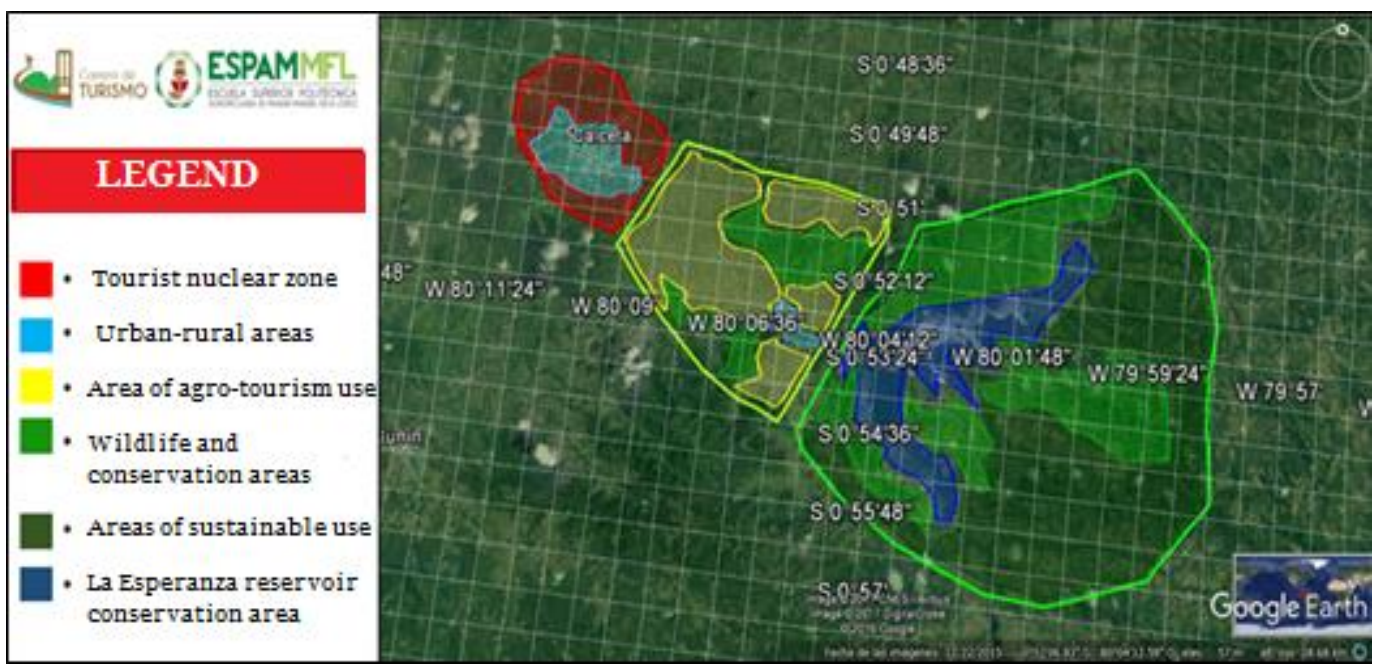

Figure 1. Tourist zoning of canton Bolívar

(Source: processing on topographic map 1: 100000 and orthophotomap) 
The strategic plan proposal for improving tourism management in Bolívar after the earthquake contains a chronogram, activities, indicators, budget and actors responsible for executing programs and projects. This enables the evaluation and monitoring of aspects such as the fulfillment of indicators established for each project, elaboration of programs and projects within the appropriate timeline, and according to the chronogram. In addition, based on the budget, the plan will serve to guarantee that expenses by programs and projects are not higher than what it was established. It is worth noting that the Bolívar Department of Tourism is the actor responsible for evaluating and monitoring all of the aforementioned aspects.

\section{CONCLUSION}

Based on the diagnosis, we verified that the April $16^{\text {th }}$ earthquake affected a great number of tourism establishments, tourist attractions and basic services that make reactivation of tourism harder. Tourism planning is one of the most inefficient areas of local tourism management. An evidence of such a reality is the lack of planning tools for addressing current problems and needs. There is little interinstitutional work between communities and the public and private sectors for developing tourism activities, with no execution of sustainable tourism projects. With regards to the established strategies, we proposed 9 programs and 19 projects that are based on the SWOT analysis, the Spatial and Territorial Development Plan, Municipality of Bolívar (2015) and the Ecuadorian Strategic Plan for Tourism Development (2020).

\section{Aknowlegments}

The authors would like to thank the engineer José Basurto Mendoza who graduated from the Tourism Engineering career at ESPAM MFL for his valuable contribution to this research.

\section{REFERENCES}

Ángeles, A. (2012). Integral Strategic Plans for the incorporation and use of Tic: Keys to manage the change. MX, Reason and Word, 17(79).

Bâca, I., (2018). A curriculum for learning nature values. Case study: learning geodiversity from Bistrita Ardeleana Gorge (Bistrita-Nasaud County, Romania). GeoJournal of Tourism and Geosites, 1(15), 1424. http://gtg.webhost.uoradea.ro/PDF/GTG-1-2015/2_155_\%20BACA.pdf

Barra, M., \& Gómez, N., (2014). Relationship between the Inputs of the Strategic Plan and the results for the Accreditation. Electronic Journal Investigative News in Education. 14 (3): 1-20.

Bermejo, G. (2014). From sustainable development according to Brundtland to sustainability as biomimesis. IS. The concept of sustainable development. Bilbao: Hegoa, p. 59.

Doumet, N., \& Yánez, Á. (2014). Strategies to develop agrotourism in the Sixto Durán Ballén dam. ESPAM Science Journal. 5(1):7-15.

Echarri, M., \& Bulnes, D. (2015). Preliminary design of the tourism development plan for selected municipalities of the Mayabeque province, Cuba (2015-2020), Ecociencia, 2(6), 1-30.

Elia, I., \& Suarez, F. (2015). Innovation of processes in tourism management: A review of the literature. Intangible Capital. 11(2):147-165. http://dx.doi.org/10.3926/ic.530.

Gandía A. (2012). Japan: Promotion of Tourism and Change in the Image of the Destination. Analysis of before and after a natural disaster.

https://riunet.upv.es/bitstream/handle/10251/17970/PROYECTO\%20\%C3\%81ngela\%20Gand\%C3\%A Da\%20Calabuig.pdf? sequence $=1$.

García, N., Carreño, A., \& Doumet, N. (2016). Strategies for the tourist development of the Bolívar canton after earthquake on April 16 (Ecuador). ECA Synergy Journal, 7(2):28-39.

González, E.A., \& Conde, E.M. (2011). Procedure to measure the tourist demand in a destination. Journal of Research in Tourism and Local Development, 4(11), 1-25. 
Kuqi, B. (2018). Teoretical Approach Concerning The Development Of Sustainable Tourism As Tourist Destination In Kosovo. GeoJournal of Tourism and Geosites, 22(2), 489-496. https://doi.org/10.30892/gtg.22218-305.

Madrid, F. (2015). Sustainability in Mexican tourism policy. PASOS. Journal of tourism and cultural heritage, 13(6):1301-1313.

Monge, J., \& Yangüe R. (2016). Sustainable tourism development Crucero Train of Ecuador. Studies and Perspectives in Tourism, 25(1):57-72.

Monterrubio, J., Sosa, P., \& Josiam, B. (2014). Spring Break and social impact in Cancun, Mexico: A study for tourism management. Tourism and Society, (15):149-166.

Morar C. (2012). Types And Forms Of Tourism In The Vadu Crisului-Suncuius Area, Romania. GeoJournal of Tourism and Geosites, 2(10), 152-161. http://gtg.webhost.uoradea.ro/PDF/GTG-22012/6_2_116_Cezar\%2oMorar.pdf.

Moreno, A. (2013). The planning and tourist management of Siem Riep / Angkor (Camboya): An approach from the archaeological destination considering its relationship with the archaeological park. PASOS, Journal of Tourism and Cultural Heritage, 11(1):107-119.

Orgaz, F. (2013). Community tourism as a tool for the sustainable development of underdeveloped destinations. Nomads Critical Journal of Social and Legal Sciences, (38):1.

Pletsch, M.A., Velázquez, V.F., Sobrinho, J.M., Borges, G.B., \& Coutinho, C.S. (2014). Geological and geomorphological elements as management tools in protected areas open to public use: A Case Study Of The Pedroso's Natural Minicipal Park, Santo André, Brazil. GeoJournal of Tourism and Geosites, 14(2), 111-124. http://gtg.webhost.uoradea.ro/PDF/GTG-2-2014/2_153_Pletsch.pdf.

Rivera, M. \& Rodríguez, L. (2012). Responsible tourism, sustainability and local community development. Córdoba: Intercultural Chair, University of Córdoba: AECIT, AACID and European Union (POCTEFEXBIOECONOMY), p. 400.

Silva, I., \& Sandoval, C. (2012). Methodology for the development of local development strategies. United Nations, CEPAL, Manual Series 76:7-99.

Tur-Viñes, V., \& Monserrat, J. (2014). The strategic communication plan. Structure and functions. Reason and Word, 18(88):1-19.

*** Ministry of Tourism of Ecuador. (2007). Ecuadorian Strategic Plan for Tourism Development (PLANDETUR, 2020). Quito. Ecuador.

*** GAD Bolívar (Decentralized Autonomous Government of the canton of Bolívar) (2016). Spatial and Territorial Development Plan, Municipality of Bolívar, 2015. http://www.municipiobolivar. gob.ec/index.php/transparencia/plan-de-desarrollo-y-ordenamiento-territorial sigadplusdiagnostico /1360000390001_DIAGNOSTICO\%20DEL\%20CANTON\%20BOLIVAR\%202014-2026_16-032015_153933.pdf.

*** Chile's Goverment. (2012). National Tourism Strategy for Chile 2012 - 2020. http://portal.mma.gob.cl/wpcontent/uploads/2014/10/1

*** General Secretariat of Risks of Ecuador (2016). Situation Reports No. 65 - 16/05/2016: Earthquake 7.8 Pedernales (16/04/2016) / Esmeraldas Replicas (18/05/2016). https://www.gestionderiesgos.gob. ec/wp-content/uploads/downloads/2016/o5/Informe-de-situaci\%C3\%B3n-n\%C2\%Bo65-especial-1605-20161.pdf.

*** National Secretary of Planning and Development of Ecuador [SENPLADES]. (2016). Evaluation of Reconstruction costs. Earthquake in Ecuador - April 2016. Executive Summary. Ecuador. http://www.planificacion.gob.ec/wp-content/plugins/downloadmonitor/download.php?id=9028\&force $=0$

Submitted:

25.09 .2018
Revised:

23.11.2018
Accepted and published online

27.11.2018 